OPEN ACCESS

Edited by:

Ning Li,

South China University of Technology,

China

Reviewed by:

Xiaoqiang $\mathrm{Ma}$,

Singapore-MIT Alliance for Research and Technology (SMART), Singapore

Heng Yin,

Dalian Institute of Chemical Physics,

(CAS), China

*Correspondence:

Maurycy Daroch

m.daroch@pkusz.edu.cn

Specialty section:

This article was submitted to

Bioprocess Engineering,

a section of the journal

Frontiers in Bioengineering and

Biotechnology

Received: 17 May 2021

Accepted: 16 July 2021

Published: 18 August 2021

Citation:

Kaczmarek MB, Struszczyk-Swita K,

Xiao M, Szczęsna-Antczak M,

Antczak T, Gierszewska M,

Steinbüchel A and Daroch M (2021)

Polycistronic Expression System for

Pichia pastoris Composed of Chitino-

and Chitosanolytic Enzymes.

Front. Bioeng. Biotechnol. 9:710922.

doi: 10.3389/fbioe.2021.710922

\section{Polycistronic Expression System for Pichia pastoris Composed of Chitino- and Chitosanolytic Enzymes}

\author{
Michal B. Kaczmarek ${ }^{1,2}$, Katarzyna Struszczyk-Swita ${ }^{2}$, Meng Xiao ${ }^{1}$, \\ Mirosława Szczęsna-Antczak ${ }^{2}$, Tadeusz Antczak ${ }^{2}$, Magdalena Gierszewska ${ }^{3}$, \\ Alexander Steinbüchel ${ }^{4}$ and Maurycy Daroch ${ }^{1 *}$
}

${ }^{1}$ School of Environment and Energy, Peking University Shenzhen Graduate School, Shenzhen, China, ${ }^{2}$ Institute of Molecular and Industrial Biotechnology, Lodz University of Technology, Lodz, Poland, ${ }^{3}$ Department of Physical Chemistry and Physicochemistry of Polymers, Faculty of Chemistry, Nicolaus Copernicus University in Toruń, Toruń, Poland, ${ }^{4}$ International Center for Research on Innovative Biobased Materials (ICRI-BioM), International Research Agenda, Lodz University of Technology, Lodz, Poland

Chitin is one of the most abundant biopolymers. Due to its recalcitrant nature and insolubility in accessible solvents, it is often considered waste and not a bioresource. The products of chitin modification such as chitosan and chitooligosaccharides are highly sought, but their preparation is a challenging process, typically performed with thermochemical methods that lack specificities and generate hazardous waste. Enzymatic treatment is a promising alternative to these methods, but the preparation of multiple biocatalysts is costly. In this manuscript, we biochemically characterised chitin deacetylases of Mucor circinelloides IBT-83 and utilised one of them for the construction of the first eukaryotic, polycistronic expression system employing self-processing $2 \mathrm{~A}$ sequences. The three chitin-processing enzymes; chitin deacetylase of $M$. circinelloides IBT-83, chitinase from Thermomyces lanuginosus, and chitosanase from Aspergillus fumigatus were expressed under the control of the same promoter in methylotrophic yeast Pichia pastoris and characterised for their synergistic action towards their respective substrates.

Keywords: chitin, chitosan, enzymatic modification, polycistronic expression, self-processing $2 \mathrm{~A}$ sequence, chitin deacetylase, chitinase, chitosanase

\section{INTRODUCTION}

Chitin is one of the most abundant, right after cellulose and lignin, naturally occurring biopolymer being the basic component of shells of crustaceans, insects and the cell walls of filamentous fungi (Al Sagheer et al., 2009; Marei et al., 2016; Ghormade et al., 2017). These are considered as burdensome waste products of marine and biotechnology industries. According to the report of the Food and Agriculture Organization of the United Nations (FAO), the estimated annual production of farmed shrimp only for Asian countries is approx. 2.5 million tons (FAO, 2017), of which 35-45\% (w/w) are waste (shells and heads), which is about 1 million tons per year (Suryawanshi et al., 2019). Currently, over $60 \%$ of biotechnology companies use fungal organisms for various purposes, including brewing, wine and bakery industries, production of antibiotics and recombinant proteins for pharmaceutical applications, production of organic acids and recombinant enzyme proteins. It is estimated that the brewing industry in Brazil, the United States and China generates approximately 2.1 million tonnes of waste yeast biomass annually (Thiago et al., 2014). The China Pharmaceutical Industry 
Association reported that more than $80 \%$ of total antibiotic production is penicillin produced by the Ascomycota species Penicillium sp. This process produces 1.2 million tonnes of biowaste per year, mainly biomass of the above-mentioned moulds (Zhang et al., 2016). Wherein, the content of chitin in the cell wall of filamentous fungi may vary from 22 to $44 \%$ depending on the class of fungi (Synowiecki and Al-Khateeb, 1997; Chatterjee et al., 2005).

Despite interesting biological properties of chitin, its application is significantly limited primarily due to the highly crystalline structure of the polymer and the lack of solubility in commonly accessible solvents (Synowiecki and Al-Khateeb, 2003). Nowadays, products of chitin modification attract a significant interest. Their distinct physico-chemical properties, solubility in numerous media, increase the spectrum of their industrial applications. At present, $\mathrm{N}$-deacetylated derivative of chitin (chitosan) and products of its degradation (chitooligosaccharides) are obtained by thermo-chemical and physical processes, which have several disadvantages (Hayes, 2012). The most important disadvantages are large amount waste that is harmful to the environment, the high energy consumption of processes and uncontrolled degradation of the polymer leading to the formation of a heterogeneous mixture of products with different physico-chemical properties, thereby affecting their biological properties (Kaczmarek et al., 2019).

Enzymatic modification of chitin and its derivatives may be a promising alternative to conventional methods. Biotransformation of chitin into chitosan through enzymatic deacetylation can be achieved with chitin deacetylases (EC 3.5.1.41). This enzymatic reaction has several advantages over the traditional chemical process, most importantly the production of chitosan with higher molecular weight and the desired degree of acetylation (Grifoll-Romero et al., 2018). Other enzymes involved in chitin and chitosan conversion are hydrolases: chitosanases (EC 3.2.1.132) and chitinases (EC 3.2.1.14). Both of them catalyse the hydrolysis of glycosidic bonds but differ in substrate specificity, the former hydrolysing bonds of chitosan and the latter of chitin (Nguyen et al., 2018). Due to the high specificities of these catalytic proteins, they are easy to control and result in products with a strictly defined chain distribution. Unfortunately, the multi-stage nature of these processes (deacetylation, depolymerisation), which are currently carried out in separated processes using disjointly operating biocatalysts, and the costs associated with obtaining each of them, make these methods economically uncompetitive.

Here we describe the synthesis of the first eukaryotic polycistronic expression system enabling the simultaneous expression of three genes encoding proteins with chitin- and chitosanolytic activity under the control of one promoter. The gene encoding chitin deacetylase from Mucor circinelloides IBT83 strain was firstly heterologously expressed in yeast Pichia pastoris and biochemically characterised. Other genes encoding chitinase from Thermomyces lanuginosus (Zhang et al., 2015) and chitosanase from Aspergillus fumigatus (Chen et al., 2012) were synthesized and used for the preparation of a polycistronic expression vector. The functioning of the this multi-gene system is based on the viral self-processing $2 \mathrm{~A}$ sequences that have been identified in Foot and Mouth disease Viruses (FMDV) belonging to the Picornaviridae family (Donnelly et al., 2001b). These short peptide sequences (approx. 20 aa) inhibits the formation of a peptide bond between C-terminal glycine and proline, causing the phenomenon of so-called ribosomal skipping, and thus spontaneous initiation of the synthesis of a new polypeptide (Donnelly et al., 2001a). The presence of several sequentially acting biocatalysts in one reaction mixture is likely to result in cascade biocatalysis under in vitro conditions thanks to the decrease of the diffusion path of intermediate metabolic products between individual biocatalysts (Liu et al., 2014), and could result in the significant reduction of the costs of the process.

\section{MATERIALS AND METHODS}

\section{Chemicals}

The following reagents were purchased: fast digest restriction enzymes: NotI, SacI and XbaI, Pierce BCA protein assay Kit, ATP solution (100 mM) (Thermo Scientific), Q5 ${ }^{\circledR}$ High-Fidelity DNA polymerase, Thermostable Taq ligase, T4 polynucleotide kinase (New England Biolabs), Taq2x MasterMix (Tiangen), DNA Clean and Concentrator ${ }^{\mathrm{TM}}-5$ (Zymo Research), Wizard ${ }^{\circledR}$ SV Gel and PCR Clean-Up System and PureYield ${ }^{\mathrm{TM}}$ Plasmid Miniprep System (Promega), Zeocin (Invitrogen), chitin from shrimp (Pandalus borealis), chitosan (MW 190-310 kDa) (Sigma Aldrich).

\section{Strains Origins and Cultivation}

The strain of filamentous fungi Mucor circinelloides IBT-83 from the culture collection of the Institute of Molecular and Industrial Biotechnology (Lodz, Poland) was used as a source of native chitin deacetylase chdaI and chdaII genes. Genes coding two native chitin deacetylases from $M$. circinelloides IBT-83 were isolated and molecularly cloned as described previously (Kaczmarek et al., 2016).

E. coli $\mathrm{DH} 5$ a transformants were grown in LB low salt medium [ $1 \%(\mathrm{w} / \mathrm{v})$ tryptone, $0.5 \%(\mathrm{w} / \mathrm{v})$ yeast extract, $0.5 \%(\mathrm{w} / \mathrm{v}) \mathrm{NaCl}]$ supplemented with $25 \mu \mathrm{g} / \mathrm{ml}$ Zeocin. LB agar plates [1\% (w/v) tryptone, $0.5 \%(\mathrm{w} / \mathrm{v})$ yeast extract, $0.5 \%(\mathrm{w} / \mathrm{v}) \mathrm{NaCl} 1.5 \%(\mathrm{w} / \mathrm{v})$ agar], supplemented with $25 \mu \mathrm{g} / \mathrm{ml}$ of Zeocin, were used to screen the pPICZaC bacterial transformant clones.

All culture media and ingredients used for Pichia pastoris experiments were prepared according to the protocol from the Easy select Pichia expression Kit (Invitrogen). Cells were grown in $250 \mathrm{ml}$ baffled shake flasks covered with two layers of cotton gauze. Pichia pastoris KM71H strain was grown in YPD medium [ $1 \%(\mathrm{w} / \mathrm{v})$ yeast extract, $2 \%(\mathrm{w} / \mathrm{v})$ peptone and $2 \%(\mathrm{w} / \mathrm{v})$ glucose]. Transformed $\mathrm{KM} 71 \mathrm{H}$ cells were grown in buffered minimal glycerol (BMD) medium [1\% (w/v) yeast extract, $2 \%(\mathrm{w} / \mathrm{v})$ peptone, $1.34 \%(\mathrm{w} / \mathrm{v})$ Yeast Nitrogen base YNB, $4 \times 10^{-5} \%$ $(\mathrm{w} / \mathrm{v})$ biotin and $1 \%(\mathrm{w} / \mathrm{v})$ glycerol, $200 \mathrm{mM}$ potassium phosphate buffer, $\mathrm{pH}$ 6.0] and buffered minimal methanol $(\mathrm{BMM})$ medium $[1 \%(\mathrm{w} / \mathrm{v})$ yeast extract, $2 \%(\mathrm{w} / \mathrm{v})$ peptone, $1.34 \%(\mathrm{w} / \mathrm{v})$ Yeast, Nitrogen base YNB, $4 \times 10^{-5} \%(\mathrm{w} / \mathrm{v})$ biotin and $0.5 \%(\mathrm{w} / \mathrm{v})$ methanol, $200 \mathrm{mM}$ potassium phosphate buffer, 
$\mathrm{pH}$ 6.0]. Transformed KM71H cells were selected on YPDS agar plates $[1 \%(\mathrm{w} / \mathrm{v})$ yeast extract, $2 \%(\mathrm{w} / \mathrm{v})$ peptone, $2 \%(\mathrm{w} / \mathrm{v})$ glucose, $2 \%(\mathrm{w} / \mathrm{v})$ agar] supplemented with $100 \mu \mathrm{g} / \mathrm{ml}$ Zeocin.

\section{Substrate Preparation}

\section{$0.5 \%$ Chitosan in Hydrochloric Acid}

The amount of $0.5 \mathrm{~g}$ of chitosan (MMW, DD 75-85\%, viscosity $200 \mathrm{cP}$ ) was mixed with $95 \mathrm{ml}$ of $0.1 \mathrm{mM} \mathrm{HCl}$ solution ( $\mathrm{pH} 4.0$ ) and left at room temperature overnight, with vigorous stirring. Next, concentrated $\mathrm{HCl}$ was added in small portions $(50-100 \mu \mathrm{l})$ to complete polymer dissolution, which was adjusted with $0.1 \mathrm{mM} \mathrm{HCl}$ to the final volume of $100 \mathrm{ml}(\mathrm{pH} \mathrm{4.5)}$.

\section{$2 \%$ Chitosan in Acetic Acid}

The amount of $2 \mathrm{~g}$ of chitosan (MMW, $78.13 \pm 0.14 \%$ viscosity $200 \mathrm{cP}$ ) was mixed with $95 \mathrm{ml}$ of $2 \%$ acetic acid and left at room temperature overnight, with vigorous stirring. Next, the solution was adjusted with $2 \%$ acetic acid to the final volume of $100 \mathrm{ml}$. The substrate prepared in this way was diluted to a concentration of $0.5 \%$ just before the reaction.

\section{Colloidal Chitin}

Colloidal chitin was prepared according to the previously published methodology (Souza et al., 2009). The amount of $5 \mathrm{~g}$ of chitin (chitin from shrimp Pandalus borealis, Sigma Aldrich) was mixed with $60 \mathrm{ml}$ of concentrated $\mathrm{HCl}$ and left at room temperature overnight, with vigorous stirring. Next, $200 \mathrm{ml}$ of ice-cold 95\% ethanol was added to the mixture and incubated overnight at $4^{\circ} \mathrm{C}$ with vigorous stirring. The precipitate was collected by centrifugation at 5,000 $\mathrm{g}$ for $20 \mathrm{~min}$ at $4^{\circ} \mathrm{C}$ and transferred to a glass funnel with filter paper $\left(80 \mathrm{~g} \mathrm{~m}^{-2}\right)$. Colloidal chitin was washed with sterile distilled water until the substrate became neutral $(\mathrm{pH} 7.0)$. Colloidal chitin was freeze-dried and stored at 4 or $-20^{\circ} \mathrm{C}$ (long term).

\section{Multiple Sequence Alignment and Phylogenetic Analysis}

The sequences of the catalytic domains (NodB) of the ChDaI and ChDaII proteins were included for multiple sequence alignment against other members of the CE4 deacetylase family. A multisequential comparison was made using Clustal Omega which use an alignment engine for aligning profile hidden Markov models (HMMs) to each other instead of the conventional dynamic programming and profile alignment (Sievers and Higgins, 2018). $\mathrm{ChDaI}$ and $\mathrm{ChDaII}$ were analysed with chitin deacetylase from Mucor rouxii MrCDA (Uniprot: P50325); chitin deacetylase from Rhizopus circinans RcCDA (Uniprot: A7UMZ0); chitin deacetylase from Gongronella butleri GbCDA (Uniprot: Q8J2N6); chitin deacetylase from Colletotrichum lindemuthianum ClCDA (PDB: 2IW0); chitin deacetylase from Pestolotiopsis sp. PesCDA (GenBank: APH81274.1); chitin deacetylase from Aspergillus nidulans AnCDA (PDB: 2Y8U); $\mathrm{CE} 4$ deacetylase isolated from the marine environment Arthrobacter sp. ArCE4A (PDB: 5LGC); peptidoglycan deacetylase from Streptococcus pneumoniae SpPgdA (PDB: 2C1G); CE4 esterase from Bacillus subtilis BsPdaA (PDB: 1W17); chitooligosaccharides deacetylase from Vibrio parahaemolyticus VpCOD (PDB: 3WX7); chitooligosaccharides deacetylase from Vibrio cholerae VcCOD (PDB: 4NY2); chitooligosaccharides deacetylase from Shewanella woodyi SbCOD (GenBank: ABN60929.1). Amino acid sequences of family CE4 CAZYmes (www.CAZY.org) were retrieved from Uniprot database, GeneBank and Protein Data Bank (PDB).

\section{Chitin Deacetylase Activity Assay}

Chitin deacetylase activity was determined based on the amount of acetic acid released during the chitosan deacetylation reaction. $1 \mathrm{ml}$ of $0.5 \%(\mathrm{w} / \mathrm{v})$ chitosan solution and $100 \mu \mathrm{l}$ of the supernatant obtained during proteins expression were preincubated for $2 \mathrm{~min}$ at $50^{\circ} \mathrm{C}$, each in separate tube. The reaction was initiated by combining both the enzyme and the polymer solution and carried out for $120 \mathrm{~min}$ at $50^{\circ} \mathrm{C}$ in stirred $(300 \mathrm{rpm})$ sterile $1.5 \mathrm{ml}$ microcentrifuge tubes. Subsequently, the samples were incubated for $20 \mathrm{~min}$ at $80^{\circ} \mathrm{C}$ to inactivate the enzyme and cooled down. The amount of acetic acid released during the reaction was determined by GC-MS gas chromatography using Stabilwax ${ }^{\circledR}$-DA; $30 \mathrm{~m}$; $0.18 \mathrm{~mm}$ ID; $0.18 \mu \mathrm{m}$ column.

\section{Effect of Temperature and Metal lons on Recombinant Chitin Deacetylase}

To determine the optimum temperature for recombinant chitin deacetylase from $M$. circinelloides IBT-83, enzymatic reactions were performed at various temperatures ranging from 20 to $70^{\circ} \mathrm{C}$. Reactions were performed according to the methodology described above. The effect of different metal ions on enzyme activity was verified by adding metal ions: $\mathrm{Cu}^{2+}, \mathrm{Fe}^{2+}, \mathrm{Mg}^{2+}$, $\mathrm{Mn}^{2+}, \mathrm{Zn}^{2+}, \mathrm{Ni}^{2+}$ to the enzymatic reaction to a final concentration of $1 \mathrm{mM}$ or $10 \mathrm{mM}$.

\section{Chitinase Activity Assay}

Chitinase activity was determined as follows: $500 \mu \mathrm{l}$ of $1 \%(\mathrm{w} / \mathrm{v})$ colloidal chitin dissolved in citric buffer $(\mathrm{pH} 4.5)$ and $250 \mu$ of the supernatant obtained during proteins expression were preincubated for $2 \mathrm{~min}$ at $50^{\circ} \mathrm{C}$, each in separate tube. The reaction was initiated by combining both the enzyme and the polymer solution and carried out for $60 \mathrm{~min}$ at $50^{\circ} \mathrm{C}$ in stirred (550 rpm) sterile $1.5 \mathrm{ml}$ microcentrifuge tube. Subsequently, the samples were incubated at $100^{\circ} \mathrm{C}$ for $5 \mathrm{~min}$ to inactivate the enzyme and cooled down. The amount of reducing sugars obtained during the reaction was determined using the Somogyi-Nelson method (Nelson, 1944).

\section{Chitosanase Activity Assay}

To chitosanase activity was determined according to the methodology described in section above. with the exception of the substrate, which in this case was $0.5 \%(\mathrm{w} / \mathrm{v})$ chitosan in $2 \%(\mathrm{v} /$ v) acetic acid solution.

\section{Determination of the Degree of Deacetylation}

The degree of deacetylation of products obtained by the action of recombinant chitin deacetylases was determined using the 
method of potentiometric titration, according to the Broussignac method (Muzzarelli et al., 1997). Precipitated and lyophilised products of the reactions were dissolved in $0.02 \mathrm{M}$ hydrochloric acid to a final concentration of $0.2 \%(\mathrm{w} / \mathrm{v})$. The solutions were then titrated with $0.1 \mathrm{M} \mathrm{NaOH}$. The two endpoints (PK) of titration observed in the diagram of $\Delta \mathrm{pH}=\mathrm{f}(\mathrm{V})$, corresponding to the titrant volumes $V_{1}$ and $V_{2}$ defined below, were determined by the first derivative method. For this purpose, plots of the dependence $\Delta \mathrm{pH} / \mathrm{V}=\mathrm{f}(\mathrm{V})$ were prepared, where $\Delta \mathrm{pH}$ and $\Delta \mathrm{V}$ denote the increments between successive changes in $\mathrm{pH}$ and the volume of the titration reagent. The deacetylation degree was calculated from the following formula:

$$
D D=\frac{M_{G l c N A c} \cdot c_{\mathrm{NaOH}} \cdot\left(V_{2}-V_{1}\right)}{m_{\mathrm{Ch}}+c_{\mathrm{NaOH}} \cdot\left(M_{G l c N A c}-M_{G l c N}\right) \cdot\left(V_{2}-V_{1}\right)} \cdot 100 \%
$$

where: $D D$-degree of deacetylation (\%), $c_{\mathrm{NaOH}}$-titrant concentration $\left(\mathrm{mol} \cdot \mathrm{dm}^{-3}\right), m_{\mathrm{Ch}}$-chitosan sample mass (g), $V_{1}$-the volume of titrant used to neutralise hydrochloric acid $\left(\mathrm{dm}^{3}\right), V_{2}$-the volume of titrant used to neutralise the sum of hydrochloric acid and protonated amine groups $\left(\mathrm{dm}^{3}\right)$, $M_{G l c N A c}$-molar mass of: 2-acetamido-2-deoxy-Dglucopyranose $\left(\mathrm{g} \cdot \mathrm{mol}^{-1}\right), M_{G l c N}$-molar mass of: 2-amino-2deoxy-D-glucopyranose $\left(\mathrm{g} \cdot \mathrm{mol}^{-1}\right)$.

\section{Chitin Deacetylases Expression Vectors Preparation}

The chdaI and chdaII (without native signal peptide) genes used for heterologous expression in P. pastoris were amplified from previously described pJET transformants (Kaczmarek et al., 2016). The selected restriction sites: NotI and XbaI were incorporated into the PCR products by using specially designed primers (chdaI_For 5'-ATTTGCGGCCGCTGACAC CTCCGCAAATTACTGG-3' chdaI_Rev $5^{\prime}$-TGCTCTAGAGC AAGTAACAAGGTAGCAATAAAGGCAG-3' , chdaII_For $5^{\prime}$ ATTTGCGGCCGCTGCTACTTCCACCAAATCCGC-3', chdaII_Rev $5^{\prime}$ - TGCTCTAGAGCGAAAATGTAAGCAGCA ACGGC- $3^{\prime}$ ). The resultant PCR products were cloned into the $P$. pastoris expression vector $\mathrm{pPICZaC} \mathrm{(Invitrogen)} \mathrm{using}$ commercially available chemocompetent cells DH5a (TianGen). The Zeocin resistant E. coli pPICZ_chdaI and pPICZ_chdaII transformants were selected by culturing on LB agar plates, supplemented with $25 \mu \mathrm{g} / \mathrm{ml}$ of Zeocin at $37^{\circ} \mathrm{C}$.

\section{Polycistronic Vector Synthesis}

\section{Generation of Plasmid for Polycistronic Expression}

A polycistronic expression vector was prepared based on the commercial vector pPICZaC. The chdaII gene was amplified from previously described pJET transformants (Kaczmarek et al., 2016) using phosphorylated chdaII_FLCR 5'-GCTACT TCCACCAAATCCGCC-3' and chdaII_RLCR_5' GAAAATGTAAGCAGCAACGGCA-3' primers. The gene coding chitinase from Thermomyces lanuginosus (Zhang et al., 2015) was enriched with the sequence coding the a-factor secretion signal, codon optimised and synthetised by Genewiz (Suzhou, China). The same approach was used for the gene coding chitosanase from Aspergillus fumigatus (Chen et al., 2012). The sequences encoding the a-factor secretory sequences preceding both genes were optimised considering the degeneracy of the genetic code, limiting the occurrence of spontaneous homologous recombination. To generate $2 \mathrm{~A}$ self-processing sequences, the ssDNA oligos were synthetised based on the P2A (ATNFSLLKQAGDVEENPGP) and T2A (EGRGSLLTCGDVEENPGP) amino acid sequences and hybridised according to the program $95^{\circ} \mathrm{C}-2 \mathrm{~min} ; 70^{\circ} \mathrm{C}-10$ $\min ; 72^{\circ} \mathrm{C}-5 \mathrm{~min} ; 4^{\circ} \mathrm{C}$-the end. The synthesis of the polycistronic vector was carried out using the LCR method (Kok et al., 2014). The above-described sequences used to synthesise the vector were amplified using phosphorylated primer sequences. Bridging oligonucleotides complementary to the ends of neighbouring DNA parts (half-bridging oligos) were designed with a target melting temperature (Tm). Figure 1 A shows the map of the expression vector and a fragment of the expression cassette. The polycistronic vector pCHIT was synthesised from six DNA fragments, the size of which ranged from $50 \mathrm{bp}$ to $3,500 \mathrm{bp}$. Individual fragments were amplified using the phosphorylated primers listed in the Supplementary Table S1.

\section{Ligase Cycled Reaction-LCR}

The LCR reaction was performed based on the modified method of Roth et al. Roth et al, (2014) as previously described by as (Liang et al., 2019). DNA fragments for a specific cycled ligation assembly reaction were mixed and diluted with ultra-pure $\mathrm{H}_{2} \mathrm{O}$ to obtain a mixture with a concentration of $20 \mathrm{nM}$ for each fragment. LCR assembly utilises single-stranded bridging oligos complementary to the ends of DNA parts to be assembled. The melting temperature of designed (half)bridging oligos was around $58-62^{\circ} \mathrm{C}$. Bridging oligonucleotides (Supplementary Table S2) were diluted with ultra-pure $\mathrm{H}_{2} \mathrm{O}$ to a final concentration of $200 \mu \mathrm{M}$. Thermostable Taq ligase (NEB) was used for the assembly reaction. The composition of the final reaction mixture $(20 \mu \mathrm{L})$ is as follows: $2 \mathrm{nM}$ for each DNA fragment, $10 \mathrm{nM}$ bridging oligonucleotides, 1xTaq ligase buffer, 5\% DMSO, and $40 \mathrm{U}$ Taq ligase. The reaction was cycled according to the following program: initial denaturation $95^{\circ} \mathrm{C}(2 \mathrm{~min})$ followed by 30 cycles of $95^{\circ} \mathrm{C}$ $(30 \mathrm{~s}), 60^{\circ} \mathrm{C}(2 \mathrm{~min})$, final incubation performed at $55^{\circ} \mathrm{C}$ $(10 \mathrm{~min})$, and samples stored at $4^{\circ} \mathrm{C}$ until transformed to E. coli DH5a (Tiangen, Beijing, China) according to the manufacturer's protocol. Figure 1B shows a simplified scheme for the synthesis of the polycistronic vector pCHIT using the LCR method.

\section{Transformation of Pichia pastoris KM71H Strains and Selection of Positive Transformants}

Plasmid DNA containing one of the genes of interest was linearised by overnight restriction digestion using SacI (Thermo Scientific). Purified, linearised plasmid ( 100 ng) was 

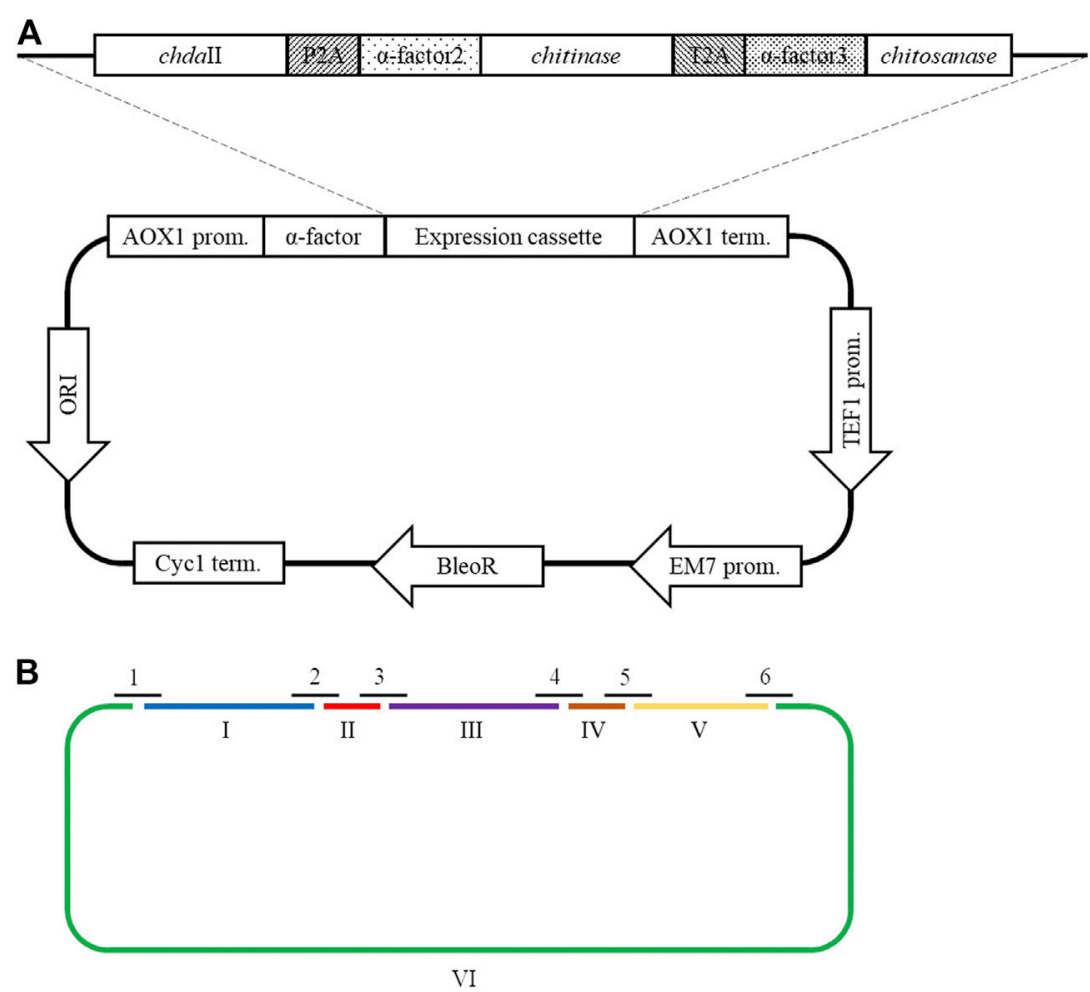

FIGURE 1 | (A) The map of the pCHIT expression vector and a fragment of the expression cassette; (B) Simplified diagram of the synthesis of a polycistronic vector pCHIT by use of LCR. 1-6 bridge sequences - black lines (Supplementary Table S2); I-VI - vector components - colored lines (Supplementary Table S1).

added into the electrocompetent KM71H cells. The prepared mixture was carefully transferred into the slide of the chilled and sterile cuvette. After electroporation (Voltage $1.5 \mathrm{kV}$, Resistance $125 \mathrm{ohms}$, Pulse length $3 \mathrm{msec}$.), cells were immediately resuspended in $500 \mu \mathrm{l}$ of $1 \mathrm{M}$ cold sorbitol. Then $500 \mu \mathrm{l}$ of YPD pH 7.5 were added into the mixture. Cells were incubated with horizontal shaking at $30^{\circ} \mathrm{C}$ for at least $3-4 \mathrm{~h}$. After transformation, cells were pelleted, $700 \mu \mathrm{l}$ of supernatant were removed, cells were resuspended in the remaining media and plated on YPDS agar plates supplemented with $100 \mu \mathrm{g} / \mathrm{ml}$ Zeocine and incubated for 2 days at $30^{\circ} \mathrm{C}$.

Colony PCR was used to confirm the presence of the expression cassette in the genome of Pichia pastoris transformants. Single colonies were replated on fresh YPD agar plates supplemented with $100 \mu \mathrm{g} / \mathrm{ml}$ Zeocine and resuspended in $10 \mu \mathrm{l}$ sterilee water, heated to $95^{\circ} \mathrm{C}$ for $5 \mathrm{~min}$, centrifuged at top speed and used as a template for PCR reaction containing Taq2x DNA MasterMix (Tiangen, Beijing, China), and universal primers (AOX1_For5' GACTGGTTCCAATTGACAAGC-3', AOX1_Rev $5^{\prime}$-GCAAAT GGCATTCTGACATCC-3' ${ }^{\prime}$ ).

\section{Pichia pastoris Cultivation Conditions}

A single colony from fresh YPD agar plates supplemented with $100 \mu \mathrm{g} / \mathrm{ml}$ Zeocine was used to inoculate $25 \mathrm{ml} \mathrm{BMGY}$ medium in a $250 \mathrm{ml}$ baffled flask and grew at $28-30^{\circ} \mathrm{C}$ in a shaking incubator (250-300 rpm) for $18 \mathrm{~h}$. The preculture with $\mathrm{OD}_{600}$ ranging from 10 to 12 was used to inoculate $100 \mathrm{ml}$ of BMGY medium in
$1,000 \mathrm{ml}$ baffled flask to final $\mathrm{OD}_{600} 0.2$ and grew until the culture reaches $\mathrm{OD}_{600} \sim 2-3$. The grown cells were harvested at $1.500-3.000 \times g$ for $5 \mathrm{~min}$ at room temperature and next resuspended in $20 \mathrm{ml}$ of BMMY medium ( $100 \mathrm{ml}$ baffled flasks covered with two layers of sterile gauze or cheesecloth). Every $24 \mathrm{~h}$, pure methanol was added to the culture to the final concentration of $0.5 \%$. The samples from $0,24,48,72$ and $96 \mathrm{~h}$ of culture were taken to measure protein concentration, prepare SDS-PAGE analysis and check the enzymatic activity of recombinant proteins.

\section{RESULTS AND DISCUSSION Chitin Deacetylases Multiple Sequence Alignment}

Previous research has shown that the strain Mucor circinelloides IBT-83 is an efficient producer of intracellular chitin deacetylase (Kaczmarek et al., 2016). However, the large amount of microbial lipids produced by this strain significantly limited the efficiency of proteins purification and their enzymatic activity (SzczesnaAntczak et al., 2006). Therefore, two genes potentially encoding chitin deacetylases chdaI and chdaII were identified by bioinformatic analysis of the genome sequence of the filamentous fungi Mucor circinelloides CBS 277.49 (Project ID: 403122, Joint Genome Institute) using Blast-2.2.30 software. The chdaI and chdaII genes amplified on the cDNA from Mucor 


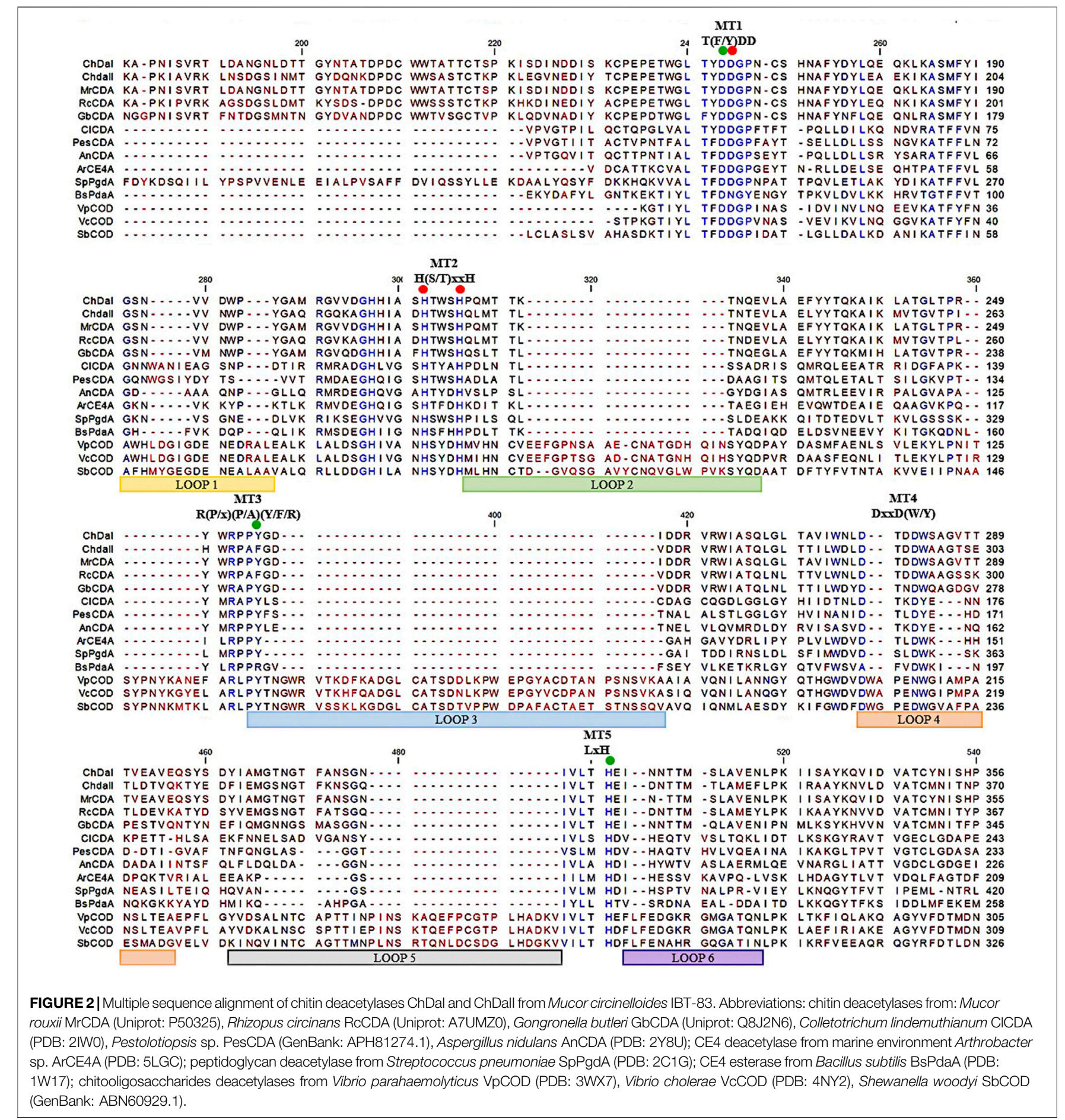

circinelloides IBT-83 cDNA, cloned and sequenced (Kaczmarek et al., 2016). The multi-sequence comparison of in silico translated $\mathrm{ChDaI}$ and $\mathrm{ChDaII}$ sequences against other members of the CE4 deacetylase family showed high homology in the area of the NodB domain, also called the catalytic domain. The obtained results presented in Figure 2 indicate the presence of five catalytic motifs MT1-5 crucial for the functioning of enzymes belonging to the CE4 esterase family:
Motif1 (MT1) corresponding to the sequence (M/Y)DD; Motif2 (MT2) H(S/T)xxH, Motif3 (MT3) R (P/x) (P/A) (Y/F/R), Motif4 (MT4) DxxD (W/Y) and the Motif5 (MT5) including the residues LxH. The Tyr255(ChDaI)/Phe269(ChDaII) (MT3) together with Asp164(ChDaI)/Asp178(ChDaII) (MT1) and His320(ChDaI)/ His334(ChDaII) (MT5) residues are directly involved in the amide bond hydrolysis reaction (Nakamura et al., 2017; Tuveng et al., 2017). Moreover, highly conserved residues 
Asp165(ChDaI)/Asp179(ChDaII) (MT1), His214(ChDaI)/ His228(ChDaII) (MT2) and His218(ChDaI)/His232(ChDaII) (MT2) form the so-called an metal-binding triad that coordinate the metal atoms; typically one of $\mathrm{Zn}^{2+}, \mathrm{Co}^{2+}, \mathrm{Ca}^{2+}$; which are co-factors of chitin deacetylases (Zhu et al., 2019). Moreover, the performed multi-sequence comparison allowed for the identification of six loops in the amino acid sequences of $\mathrm{ChDaI}$ and ChDaII proteins. Crystallographic studies carried out previously (Andrés et al., 2014) showed that these loops are located in close proximity to the active centre of the enzyme and are involved in "capturing" the substrates subjected to deacetylation reactions.

\section{EXPRESSION AND ENZYMATIC ACTIVITY OF CHITIN DEACETYLASES CHDAI AND CHDAII FORM M. CIRCINELLOIDES IBT-83}

The multi-sequence comparison of the amino acid sequences of the $\mathrm{ChDaI}$ and $\mathrm{ChDaII}$ proteins suggest that the genes chdaI and chdaII identified in the filamentous fungi M. circinelloides IBT-83 encode these enzymes exhibiting chitin deacetylase activity. The fungal chitin deacetylases known so far are glycoproteins, for which the post-translational attachment of sugar residues, mainly mannose, is crucial for the proper functioning of enzymes. Chitin deacetylase from Mucor rouxii has been identified as a monomeric protein with a high content of linked mannose residues (Martinou et al., 1993). Another example of a highly glycosylated chitin deacetylase is an enzyme isolated from soil fungi of the genus Mortierella sp. Importantly, the enzymatic deglycosylation performed at this glycoprotein resulted in a complete loss of catalytic activity (Zhao et al., 2011). Our attempts to functionally express the $M$. circinelloides IBT-83 chda genes in E. coli were also unsuccessful (results not shown). This is most likely due to inability of this prokaryotic host to carry out the necessary post-translonational modifications. Analysis of the amino acid sequences of the $\mathrm{ChDaI}$ and ChDaII proteins using bioinformatic tools NetNGlyc 1.0 (http://www.cbs.dtu.dk/services/NetNGlyc/) and NetOGlyc 4.0 (http://www.cbs.dtu.dk/services/NetOGlyc/) showed that both proteins have numerous sites of potential $\mathrm{N}$ and O-glycosylation. Due to the ability to carry out posttranslational modifications and the simplicity of genetic manipulation, the yeast Pichia pastoris was selected as an efficient host organism for heterologous gene expression. The open reading frames ORF (without native signal sequences, 21 aa.) encoding $\mathrm{ChDaI}$ and $\mathrm{ChDaII}$ were successfully cloned and transformed into Pichia pastoris $\mathrm{KM} 71 \mathrm{H}$ for and targeted for extracellular expression. The theoretical mass of recombinant proteins enriched with the $\mathrm{C}$-terminal $6 \mathrm{xHis}$ tag and $M y c$ Tag was 50.8 and $51.7 \mathrm{kDa}$ for $\mathrm{ChDaI}$ and $\mathrm{ChDaII}$, respectively. Figure 3 shows the results of electrophoretic analysis (SDS-PAGE) of proteins present in the culture medium obtained after culturing selected KM71H_pPICZ_chdaI and KM71H_pPICZ_ chdaII transformants expressing proteins, $\mathrm{ChDaI}$ and $\mathrm{ChDaII}$, respectively. Electrophoretic analysis showed that the mass of deacetylase $\mathrm{I}-\mathrm{ChDaI}$ is approx. $48 \mathrm{kDa}$, while the mass of the second expressed protein - ChDaII is approx. $49 \mathrm{kDa}$. It is surprising that the actual molecular weight of the obtained recombinant chitin deacetylases from $M$. circinelloides IBT-83 are smaller than the determined theoretical weight of the proteins. However, it should be remembered that the migration of proteins in the SDS environment, in addition to size, may also be dependent on the structural properties of proteins themselves, their charge, and the ability to bind SDS while forming micelles. The prior research showed that for membrane proteins, the difference between the theoretical mass and the experimental mass determined during SDSPAGE analysis could be as high as 48\% (Rath et al., 2009). Moreover, P. pastoris yeast produces numerous extracellular proteolytic enzymes responsible for the hydrolysis of peptide bonds from the N-terminal end of proteins (Sinha et al., 2005). However, peptide mapping analysis performed on proteins extracted from the gel bands indicated that the recombinant proteins were chitin deacetylases.

The analysis of the enzymatic activity of chitin deacetylases, carried out for the culture medium from different time points of cultivation, showed that deacetylase II has $74 \%$ higher maximum specific activity compared to deacetylase I. Figure 4 shows the dependence of the specific activity of $\mathrm{ChDaI}$ and ChDaII on the duration of the methanol-induced culture. Both enzymes showed the highest specific activity after $48 \mathrm{~h}$ of cultivation, which was $220.47 \mathrm{mU} \mathrm{mg}^{-1}$ of protein and $836.12 \mathrm{mU} \mathrm{mg}^{-1}$ for $\mathrm{ChDaI}$ and ChDaII, respectively. The specific activity of chitin deacetylase II adjusted for the protein concentration determined on the basis of the band intensity corresponding to the recombinant protein (Figure 3) was $3.57 \mathrm{U} \mathrm{mg}^{-1}$ (Supplementary Figure S4). The analysis of the products obtained as a result of the ChDaII activity, showed a significant increase in the degree of polymer deacetylation (DD). The average DD of the products was $96.0 \pm$ $1.6 \%$ in relation to the substrate, the degree of deacetylation of which was DD $78.13 \pm 0.14 \%$. Since deacetylase II showed a much higher catalytic activity compared to deacetylase I, only isoform II of chitin deacetylase from Mucor circinelloides IBT-83 was subjected to further analyses.

Analysis of the biochemical properties of the recombinant chitin deacetylase from Mucor circinelloides IBT-83 allowed the determination of the optimal temperature for the action of the recombinant enzyme. The highest activity of ChDaII was determined for the reaction temperature of $50^{\circ} \mathrm{C}$. Exceeding this value results in a drastic decrease in activity by approx. $90 \%$ for the temperature of $60^{\circ} \mathrm{C}$ and almost complete loss of $\mathrm{ChDaII}$ catalytic activity at $70^{\circ} \mathrm{C}$ (Table 1). Most fungal chitin deacetylases studied so far show the highest catalytic activity at $50^{\circ} \mathrm{C}$. However, chitin deacetylases with distinct properties are also known. An example is chitin deacetylase from Rhizopus circinans, for which the optimal temperature was $37^{\circ} \mathrm{C}$ (Gauthier et al., 2008). On the other hand, native deacetylase from C. lindemuthianum showed higher thermostability and the highest activity at $60^{\circ} \mathrm{C}$ (Tokuyasu et al., 1996).

Chitin deacetylases, including those of fungal origin, belong to the group of metalloenzymes. Divalent metal ions act as enzyme cofactors that are coordinated by side groups of amino acids 

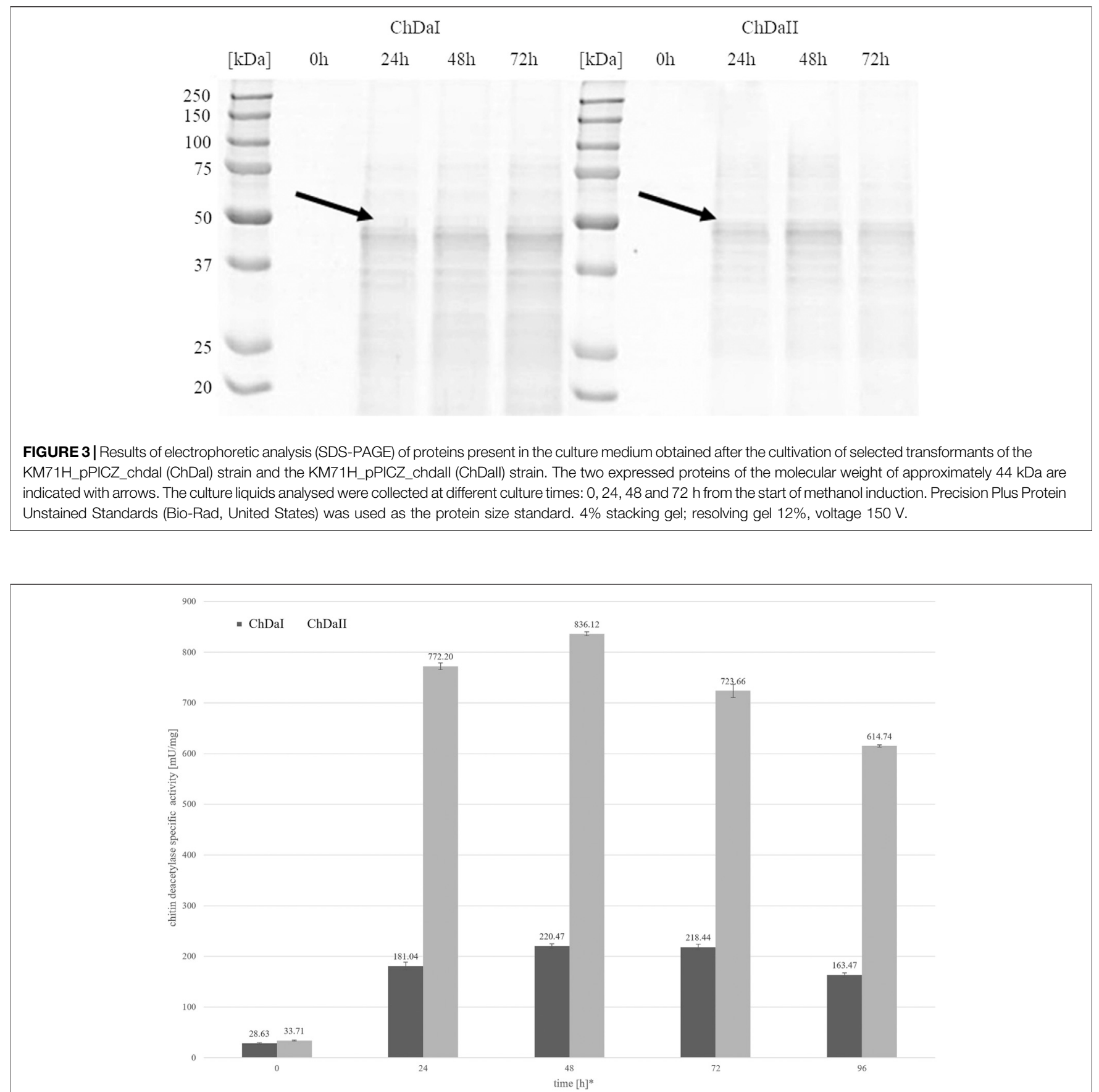

FIGURE 4 | Relationship between the specific activity of chitin deacetylases and the time of cultivation. The enzymatic preparations were made from the culture medium obtained after the cultivation of transformants exhibiting the highest chitin deacetylases activity. ${ }^{\star}$ Cultivation time measured from the start of methanol-induced expression of ChDal and ChDall.

belonging to the metal-binding triad (Figure 2). Table 2 shows the results of the percentage change in the enzymatic activity of recombinant chitin deacetylase II from $M$. circinelloides IBT-83 for reactions carried out in a medium enriched with divalent metal ions at a concentration of $1 \mathrm{mM}$ or $10 \mathrm{mM}$, compared to the control for which the reaction medium was not enriched with metal ions. The obtained results clearly indicate a high dependence of the recombinant enzyme activity on the type and concentration of bivalent ions. The use of $\mathrm{Cu}^{2+}$ and $\mathrm{Ni}^{2+}$ ions significantly inhibited the activity of the tested enzyme by $44-94 \%$. For $\mathrm{Fe}^{2+}$ ions, a decrease in activity was observed only at the concentration of metal ions at $10 \mathrm{mM}$. The enzyme activity 
TABLE 1 | Effect of reaction temperature on the activity of recombinant chitin deacetylase ChDall from Mucor circinelloides IBT-83. The culture medium obtained after $48 \mathrm{~h}$ of cultivation of the selected transformant was used as the enzyme preparation.

\begin{tabular}{lc} 
Reaction temperature $\left({ }^{\circ} \mathbf{C}\right)$ & $\begin{array}{c}\text { ChDall } \\
\left.\text { activity } \mathbf{( m U} \mathbf{~ m l}^{-\mathbf{1}}\right)\end{array}$ \\
\hline $\mathbf{2 0}$ & 34.6 \\
$\mathbf{3 0}$ & 171.3 \\
$\mathbf{4 0}$ & 212.7 \\
$\mathbf{5 0}$ & 288.5 \\
$\mathbf{6 0}$ & 29.8 \\
$\mathbf{7 0}$ & 1.9
\end{tabular}

TABLE 2 | Percentage change in enzymatic activity of recombinant chitin deacetylase ChDall from Mucor circinelloides IBT-83. The culture medium obtained after $48 \mathrm{~h}$ of cultivation of the selected transformant was used as the enzyme preparation.

\begin{tabular}{|c|c|c|}
\hline \multirow[t]{2}{*}{ Metal ions } & \multicolumn{2}{|c|}{$\begin{array}{c}\text { Percentage change in enzymatic } \\
\text { activity (\%) }\end{array}$} \\
\hline & $1 \mathrm{mM}$ & $10 \mathrm{mM}$ \\
\hline Control & 100 & 100 \\
\hline $\mathrm{Cu}^{2+}$ & 56 & 11 \\
\hline $\mathrm{Fe}^{2+}$ & 98 & 80 \\
\hline $\mathrm{Mg}^{2+}$ & 119 & 112 \\
\hline $\mathrm{Mn}^{2+}$ & 109 & 98 \\
\hline $\mathrm{Zn}^{2+}$ & 135 & 79 \\
\hline $\mathrm{Ni}^{2+}$ & 12 & 6 \\
\hline
\end{tabular}

increased in the presence of $\mathrm{Mg}^{2+}$ ions at concentrations of 1 and $10 \mathrm{mM}$ and $\mathrm{Mn}^{2+}$ ions at a concentration of $1 \mathrm{mM}$. Interesting results were observed using $\mathrm{Zn}^{2+}$ ions as the enzyme cofactor. For the concentration of $1 \mathrm{mM}$, an increase in chitin deacetylase activity as much as $35 \%$ was observed. Increasing the concentration of metal ions to $10 \mathrm{mM}$ resulted in a decrease in activity by $21 \%$. Literature data show that the effect of individual metal ions on the activity of chitin deacetylases isolated from various microorganisms, mainly fungi, vary from protein to protein and it is difficult to determine the direct relationship between the amino acid sequence of proteins and their response to the presence of individual metal ions in the reaction environment. The closely related, native chitin deacetylase from $M$. rouxii ( $\mathrm{r} r \mathrm{CDA}$, Figure 2) showed increased activity after incubation in a buffer enriched with $\mathrm{Zn}^{2+}$ ions $(1 \mathrm{mM})$, while the use of $\mathrm{Mn}^{2+}$ ions inhibited the biocatalyst (Kołodziejska et al., 1999). On the other hand, both $C$. lindemuthianum chitin deacetylase (ClCDA) and ChDaII were significantly inhibited by $\mathrm{Ni}^{2+}$ ions despite significant sequence differences within the catalytic motifs. Furthermore, $\mathrm{Mn}^{2+}$ ions at a concentration of $10 \mathrm{mM}$ limited only the activity of native ClCDA (Tokuyasu et al., 1996). Moreover, native and recombinant enzymes derived from the same microorganisms may also show different effects of metal ions on their activity. The previous studies showed that the activity of the native chitin deacetylase from Rhizopus circinans is increased in the presence of $\mathrm{Mn}^{2+}$ and $\mathrm{Mg}^{2+}$ ions ( $1 \mathrm{mM}$ ) and was strongly inhibited by $\mathrm{Cu}^{2+}$ ions (Gauthier et al., 2008). The recombinant enzyme showed no significant changes in activity due to the presence of manganese and magnesium ions, however, like the native protein, it was strongly inhibited by $\mathrm{Cu}^{2+}$ ions. Chitin deacetylase from $C$. lindemuthianum expressed in $P$. pastoris also showed different properties than the native enzyme (Blair et al., 2006).

\section{Polycistronic Expression Vector Synthesis}

The factor limiting the use of enzymatic methods in large-scale modification of chitin substrates is the high crystalline structure of the polymer. Crystallinity limits the availability of reactive groups present in the polymer chains for enzyme action. This phenomenon is often observed in case of chitin deacetylases (Pareek et al., 2013). Moreover, the bioconversion of chitin substrates to chitooligosaccharides with the desired chain arrangement requires the action of several enzyme preparations, which increases costs of these processes. The currently used conventional thermo-chemical and chemical methods have many disadvantages, with uncontrolled degradation of polymers as the most important one. The latter results in a mixture of heterogeneous products (Struszczyk, 2000). Nevertheless, high efficiency and low costs mean that they are still used in industrial processes. It is expected that simultaneous expression of three genes encoding proteins with chitin- and chitosanolytic activity under the control of one promoter might increase the efficiency of enzymatic processes and reduce the costs associated with the production of biocatalysts. A polycistronic expression vector incorporating the genes of chitin deacetylase ChDaII, chitinase from Thermomyces lanuginosus, and chitosanases from Aspergillus fumigatus was prepared employing the LCR method. Ligase cycled reaction is an efficient and powerful tool to assemble many DNA fragments in a single reaction. The selections of genes encoding chitinase and chitosanase were based on the results of biochemical analysis of recombinant chitin deacetylase ChDaII from Mucor circinelloides IBT-83. Analysis of the literature data showed that the best candidate for heterologous expression of chitinase was chitinase1 (Chit1) from Thermomyces lanuginosus, which was already heterologously expressed in $P$. pastoris GS115 strain. The optimal temperature for this enzyme was $50^{\circ} \mathrm{C}$, while the optimal $\mathrm{pH}$ of the reaction medium was $\mathrm{pH} 5.0$ (Zhang et al., 2015). The advantage of this biocatalyst, compared to the other candidates, was that it exhibits satisfactory exo- and endochitinolytic activity against native chitin derived from powdered shrimp shells. The selected chitosanase from Aspergillus fumigatus was also successfully heterologously compressed in $P$. pastoris GS115. The recombinant enzyme showed high activity over a wide $\mathrm{pH}$ range from 4 to 7 . The optimal temperature of its activity was $60^{\circ} \mathrm{C}$, however, at $50^{\circ} \mathrm{C}$ it showed catalytic activity exceeding $80 \%$ of the maximum activity. Like native $\mathrm{ChDaII}$, the chitosanase from $A$. fumigatus contained an $\mathrm{N}$-terminal signal sequence of 17 amino acids (Chen et al., 2012). To avoid potential problems with the 


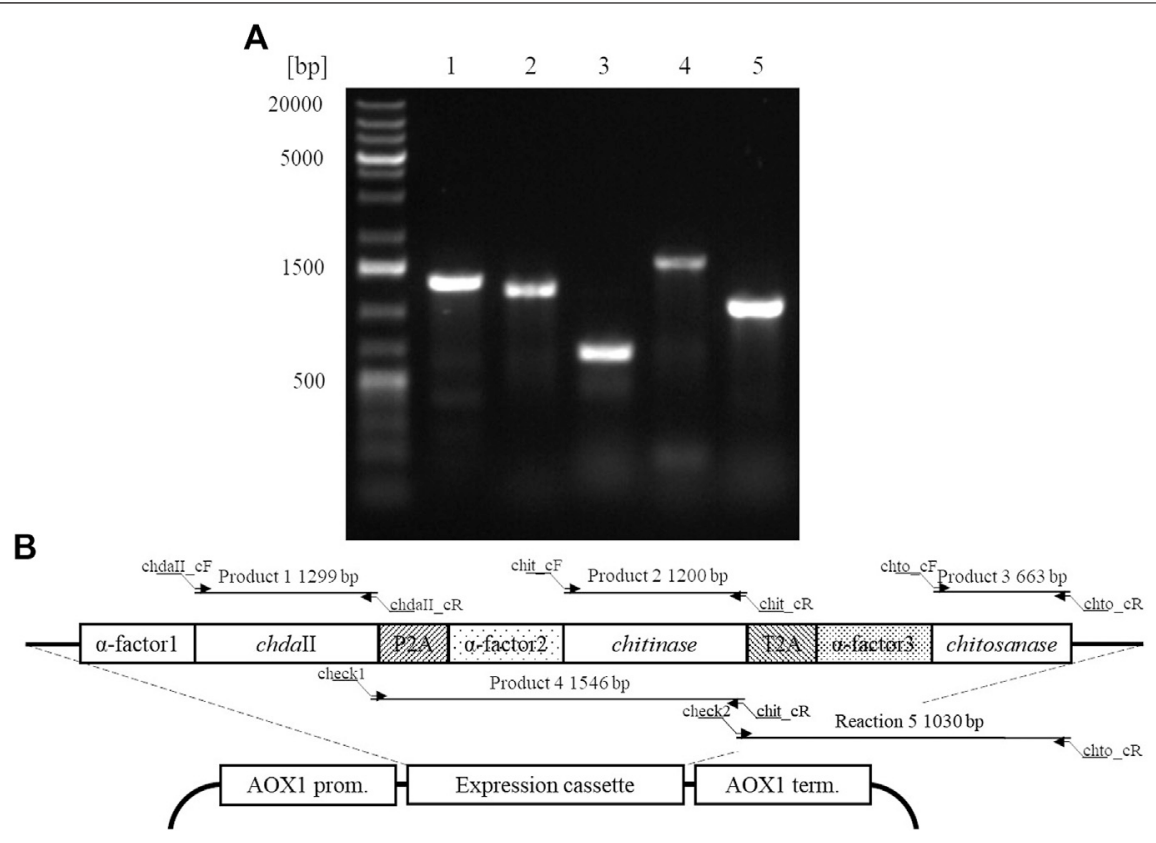

FIGURE 5|A. Electrophoretic analysis of products obtained by Colony PCR analysis (SupplementaryTable S3) carried out for a selected transformant $P$. pastoris $\mathrm{KM} 71 \mathrm{H} \_$pCHIT. Map of the expression cassette of the polycistronic vector pCHIT with marked sizes of products obtained as a result of PCR colony analyses.

presence of the native signal peptide, a gene lacking this sequence was used for the preparation of the polycistronic vector $\mathrm{pCHIT}$. The genes coding each enzyme were separated by two different A2 self-processing sequences. Verification of the assembly was performed with a series of PCR reactions using appropriate primers (Supplementary Table S3). Figure 5A shows the results of the electrophoretic analysis of PCR reaction products. The efficiency of assembling six DNA fragments, the size of which ranged from $50 \mathrm{bp}$ to $3,500 \mathrm{bp}$, was $50 \%$. Prior research showed that the LCR method allows for the assembly of eight fragments with efficiency reaching even $90 \%$. (Roth et al., 2014). For each of the three enzymes $\alpha$-factor secretion signal was used to guide the secretion of recombinant proteins. This approach was used to ensure a similar efficiency of expression and secretion of individual proteins. The degeneracy of the genetic code was used in the optimisation of secretory sequences to reduce the risk of homologous recombination between the enzymes and subsequent loss of function. Despite these efforts, these sequences showed a relatively high homology, which could have exerted an impact on the correct synthesis of the pCHIT vector. Similar sequence homology problems were observed for the viral A2 selfprocessing sequences. These sequences show little interspecies variability, which can also impede the correct synthesis of the polycistronic vector pCHIT. In the light of these sequence homology challenges, the efficiency of the process reaching $50 \%$ can be considered a success. De Kok et al. (2014) proved that a similar efficiency of DNA fragment assembly could be obtained only with the use of yeast recombination mechanisms. However, LCR assembly provides a much faster and easier workflow than recombination in vivo.

\section{Expression of Three Enzymes From the Polycistronic Vector}

The correctly synthesised polycistronic expression vector was linearised with SacI and electroporated into Pichia pastoris KM71H cells. Selected transformants, for which integration of the expression vector into the host genome was confirmed by colony PCR, were subjected to methanol-induced heterologous expression. Figure 6 shows the results of electrophoretic analysis (SDS-PAGE) of proteins present in the culture medium obtained after culturing the selected KM71H_pCHIT transformant. The gels show three biosynthetic products, the mass of which ranged from 46 to $48 \mathrm{kDa}$ for product 1 and 2 (chitin deacetylase ChDaII from Mucor circinelloides IBT-83 and chitinase from T. lanuginosus, both enriched with their A2 self-processing sequences, respectively), and about $27 \mathrm{kDa}$ for product 3 (chitosanase from $A$. fumigatus). According to the mechanism of functioning of A2 selfprocessing sequences, the gene preceding the viral sequence will be enriched with the $\mathrm{N}$-terminal fragment of these sequences. Therefore, the theoretical mass of chitin deacetylase II from M. circinelloides IBT83 enriched with an 18 amino acid fragment of P2A sequence was $49 \mathrm{kDa}$, while the predicted mass of recombinant chitinase from $T$. lanuginosus with a 17 amino acid N-terminal fragment of the T2A sequence was $45.9 \mathrm{kDa}$. The obtained products 1 and 2 (Figure 6) correspond to $\mathrm{ChDaII}+\mathrm{P} 2 \mathrm{~A}$ chitin deacetylase and T. lanuginosus chitinase enriched with $\mathrm{T} 2 \mathrm{~A}$ sequences. As it was mentioned, chitinase from T. lanuginosus was already expressed in P. pastoris GS115 strain, and its mass was $44.1 \mathrm{kDa}$. However, this variant was not enriched 


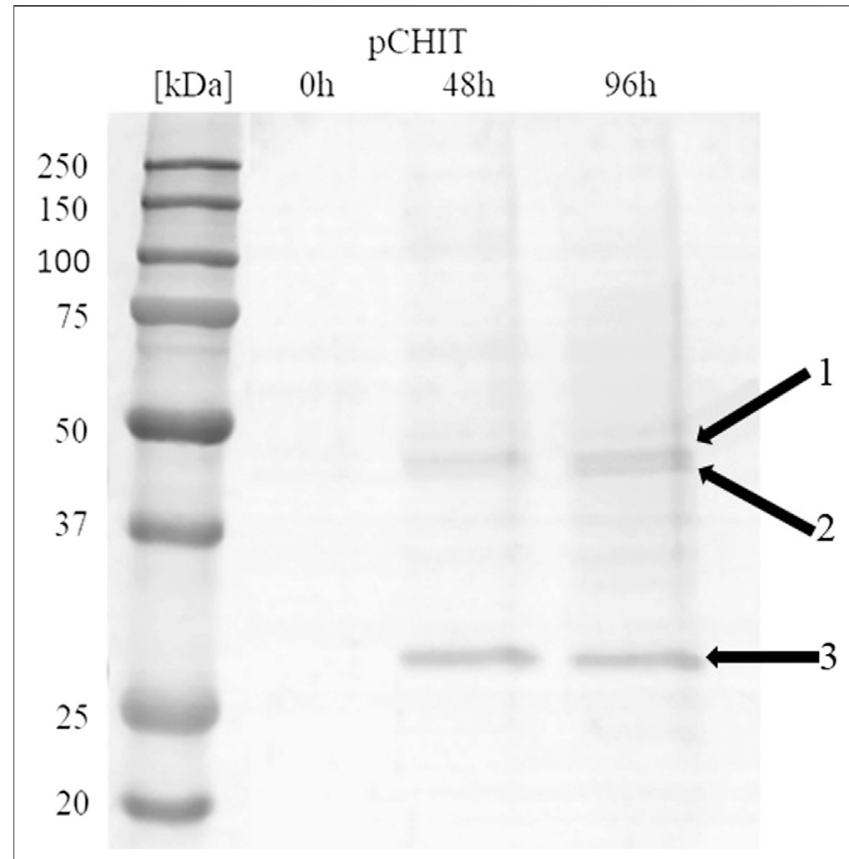

FIGURE 6 | Electrophoretic analysis (SDS-PAGE) of proteins present in the after-culture medium obtained after culturing selected $\mathrm{KM} 71 \mathrm{H} \_\mathrm{pCHIT}$ transformant. Arrows indicate following expressed proteins: 1-recombinant chitin deacetylase ChDall from Mucor circinelloides IBT-83 enriched with an 18 amino acid fragment of P2A sequence $M_{w} \sim 48 \mathrm{kDa}$; 2 -recombinant chitinase from $T$. lanuginosus enriched with a 17 amino acid fragment of T2A sequence $M_{w} \sim 46 \mathrm{kDa}$; recombinant chitosanase from $A$. fumigatus $\mathrm{M}_{\mathrm{w}} \sim 27 \mathrm{kDa}$. The culture liquids analysed were collected at different culture times: 0, 24, 48 and $72 \mathrm{~h}$ from the start of methanol induction. Precision Plus Protein Unstained Standards (Bio-Rad, United States) was used as the protein size standard. $4 \%$ concentrating gel; developing gel 12\%, voltage $150 \mathrm{~V}$.

with the T2A viral sequence (Zhang et al., 2015). The weight of the third product ( $27 \mathrm{kDa}$, Figure 6) differs from the theoretical weight of chitosanase from $A$. fumigatus, which was $23.6 \mathrm{kDa}$. The results earlier showed that the recombinant chitosanase from A. fumigatus has a mass of approx. $28 \mathrm{kDa}$ when expressed in P. pastoris (Chen et al., 2012). Most likely, it proves a relatively high protein glycosylation (approx. $18.6 \%$ in relation to the protein mass). Bioinformatic analysis showed that this enzyme has several potential O-linked glycosylation sites and one potential N-linked glycosylation site. Moreover, it may be related to the process of cleavage of the secretory sequence by the native KEX2 proteinase produced by the yeast $P$. pastoris (Kjeldsen, 2000). The theoretical mass of chitosanase, taking into account the secretory sequence, is approx. $32 \mathrm{kDa}$.

Recombinant proteins extracted from the two electrophoretic bands were subjected to peptide mapping analysis. Trypsin digestion was performed with proteins extracted from the upper band potentially containing $M$. circinelloides IBT-83 chitin deacetylase and $T$. lanuginosus chitinase and the lower band containing $A$. fumigatus chitosanase. The obtained peptides (from the upper band) were aligned with the T. lanuginosus chitinase sequence (GenBank accession number AIW06013.1) and the $M$. circinelloides $f$. lusitanicus CBS 277.49 chitin deacetylase sequence (GenBank accession number OAD01792.1). Protein sequence coverage was
62 and 6\%, respectively, for recombinant chitinase from $T$. lanuginosus (Supplementary Figure S1) and ChDaII from $M$. circinelloides IBT-83 (Supplementary Figure S2). Peptides obtained after digestion of the lower band protein were aligned with the endochitinase sequence from Asperillus sp. CJ22-326 (GenBank accession number ABZ88800.1) with the protein sequence coverage at 39\% (Supplementary Figure S3). The obtained results clearly indicated the presence of recombinant proteins in the culture medium confirming the correct functioning of the A2 self-processing viral sequences.

Viral self-processing A2 sequences have been successfully used for multi-gene polycistronic expression in cells of various eukaryotes, incl. human and mouse cell lines, plants and yeast cells (Geier et al., 2015). The advantage of using A2 sequences for multi-gene expression is their small size compared to IRES (Internal Ribosome Entry Sites) sequences, which significantly reduces the size of multi-gene constructs, and thus facilitates their transformation into efficient producer organisms. Early studies showed that the amount of proteins obtained from the expression of genes upstream and downstream of A2 sequences is the same or very similar (Halpin et al., 1999). This was supposed to be another advantage over IRES sequences. Subsequent in vitro analysis of the translation process showed some disproportions in the amount of proteins expressed using the A2 sequence. De Felipe et al. (De Felipe et al., 2006) showed that proteins encoded ahead of A2 sequences are produced in a slightly higher amount than proteins that genes are located behind them. These differences, however, were not as significant as when the IRES sequence was used. Our results may indicate that the expression efficiency of such polycistronic systems also depends on the size of the expressed genes. The band indicating the presence of chitosanase, the smallest and the third of the three co-expressed genes, appeared in the culture medium in the highest amounts (Figure 6). It is unclear at this stage as to whether this difference is due to translation, folding or protein export.

\section{ENZYMATIC ACTIVITY OF THE MULTI-ENZYME COCKTAIL}

The culture medium obtained after $96 \mathrm{~h}$ of methanol-induced cultivation of $P$. pastoris KM71H_pCHIT strain was analysed for the activity of chitin deacetylase, chitinase and chitosanase Table 3). The activity of recombinant chitin deacetylase was $372 \mathrm{mU} \mathrm{mg} \mathrm{mg}^{-1}$ of protein. However, taking into account the intensity of the band peptide identified as chitin deacetylase II shown in Figure 6, the adjusted specific activity of the recombinant enzyme was 3.97 $\mathrm{U} \mathrm{mg}^{-1}$ (Table 3; Supplementary Figure S4). The obtained results indicate that the specific activity of the enzyme expressed in the multigene system is slightly higher than that of ChDaII after expression of the monogenic vector. This may indicate the synergistic action of biocatalysts in the multi-enzyme cocktail. Pre-hydrolysis of the glycosidic bonds loosens the dense structure of the chitin substrate, thereby increasing the availability of acetyl residues for the action of chitin deacetylase. The degree of deacetylation of the products obtained by the action of ChDaII chitin deacetylase from the multigene system reached $85.22 \pm 0.17 \%$. 
TABLE 3 | Enzymatic activity determined in the post-culture liquid obtained after expression of the pCHIT transformants.

\begin{tabular}{|c|c|c|c|c|c|c|}
\hline Enzyme & Substrate & $\begin{array}{l}\text { Protein concentration } \\
\qquad\left(\mathrm{mg} \mathrm{ml}^{-1}\right)\end{array}$ & $\begin{array}{c}\text { Activity (U } \\
\left.\mathrm{ml}^{-1}\right)\end{array}$ & $\begin{array}{l}\text { Specific activity } \\
\qquad\left(\mathrm{U} \mathrm{mg}^{-1}\right)\end{array}$ & $\begin{array}{l}\text { Adjusted protein } \\
\text { concentration } \\
\left(\mathrm{mg} \mathrm{ml}^{-1}\right)^{\mathrm{a}}\end{array}$ & $\begin{array}{c}\text { Adjusted specific } \\
\text { activity } \\
\left(\mathrm{U} \mathrm{mg}^{-1}\right)^{\mathrm{a}}\end{array}$ \\
\hline Chitin deacetylase & $0.5 \%$ chitosan $^{b}$ & 0.68 & 0.25 & 0.37 & 0.063 & 3.97 \\
\hline Chitinase & Colloidal chitin & & 1.99 & 2.93 & 0.039 & 51.03 \\
\hline Chitosanase & $0.5 \%$ chitosan $^{c}$ & & 3.46 & 5.09 & 0.295 & 11.73 \\
\hline
\end{tabular}

${ }^{a}$ Determined on the basis of the intensity of the band corresponding to the recombinant protein.

${ }^{b}$ Dissolved in hydrochloric acid.

${ }^{c}$ Dissolved in $2 \%$ acetic acid.

The activities of recombinant chitinase and chitosanase were determined by measuring the concentration of reducing sugars. Since both enzymes were present in the culture medium used as the enzyme preparation, it was assumed that recombinant chitinase from $T$. lanuginosus shows activity against colloidal chitin, while recombinant chitosanase from $A$. fumigatus was active only against chitosan dissolved in $2 \%(\mathrm{v} / \mathrm{v})$ acetic acid. However, it should be remembered that acetylated (GlcNAc) and deacetylated (GlcN) residues occur in both chitin and chitosan and can be hydrolysed by both enzymes. Determined in this way, the specific activity of the recombinant chitinase was $2.9 \mathrm{U} \mathrm{mg}^{-1}$. Determined based on densitometric analysis of the SDS gel (Figure 6; Supplementary Figure S4), the concentration of recombinant chitinase was $63 \mu \mathrm{g}$ $\mathrm{ml}^{-1}$, which allowed to determine the adjusted specific activity of $51.03 \mathrm{U} \mathrm{mg} \mathrm{m}^{-1}$. Recombinant chitinase from $T$. lanuginosus expressed in $P$. pastoris GS115 in addition to activity against synthetic substrates such as: 4-nitrophenyl N,N'-diacetyl- $\beta$-Dchitobioside (exochitinolytic, $30 \mathrm{mU} \mathrm{mg}^{-1}$ ) and 4-nitrophenyl $\beta-\mathrm{D}-\mathrm{N}, \mathrm{N}^{\prime}, \mathrm{N}^{\prime \prime}$ - triacetylchitotriose (endochitinolytic, $150 \mathrm{mU}$ $\mathrm{mg}^{-1}$ ), also showed activity against colloidal chitin. However, this value was not disclosed (Zhang et al., 2015). Chitinase from Bacillus licheniformis expressed in P. pastoris KM71H yeast showed a specific activity of $3.4 \mathrm{mU} \mathrm{mg}{ }^{-1}$ protein in the culture medium (Menghiu et al., 2019). On the other hand, chitinase from Streptomyces albolongus ATCC 27414 expressed in E. coli BL21 bacteria showed specific activity against colloidal chitin of as much as $66.2 \mathrm{Umg}^{-1}$ of protein (Guo et al., 2019). This indicates the wide range of activities that biocatalysts from various sources exhibit.

The activity of the third enzyme expressed in the polycistronic system pCHIT was $5.2 \mathrm{U} \mathrm{mg}^{-1}$ against $0.5 \%$ (w/v) of chitosan dissolved in acetic acid. After taking into account the concentration of recombinant chitosanase in the after-culture medium (determined on the basis of the intensity of the band), the corrected specific activity was $11.73 \mathrm{U} \mathrm{mg}^{-1}$ (Table 3; Supplementary Figure S4). Previous studies focused on the expression of this enzyme in the yeast P. pastoris GS115 at the bioreactor scale of (Chen et al., 2012). The pre-purified recombinant chitosanase obtained from $A$. fumigatus showed a specific activity of $8.3 \mathrm{U} \mathrm{mg}^{-1}$. The higher activity of the enzyme obtained in our research may be due to the fact that recombinant chitinase hydrolysing glycosidic bonds on acetylated units was also present in the reaction mixture. The chitosan used as a substrate for the determination of chitosanase activity showed a deacetylation degree of $78.13 \pm 0.14 \%$. This indicates that acetylated units susceptible to the action of recombinant chitinase were present in the substrate. The ability of the multi-enzyme cocktail to modify colloidal chitin was confirmed by GPC/SEC analysis of products obtained as a result of the action of recombinant proteins present in the after-culture medium (Supplementary Figure S5). The number-average (Mn) and weight-average $(\mathrm{Mw})$ molar masses of the substrate and the obtained products determined on the basis of the obtained results clearly indicate the occurrence of the enzymatic depolymerization of colloidal chitin (Supplementary Table S4). Meanwhile the polydispersity index $\sim 1.0$ indicates that there is a high degree of homogeneity among these degradation products suggesting that chitooligosaccharides of similar chain length have been synthesized. Unfortunately, the set of columns used in the analysis did not allow to accurately determine the masses of the products obtained during enzymatic degradation of the biopolymer.

To the best of our knowledge, our research is the first attempt at a comprehensive, multi-enzymatic modification of chitin substrates using a mixture of several enzymes belonging to different classes and produced by one host. Chyleński et al. used Design of Experiment (DoE) approach to create highly efficient enzyme cocktails for the complete enzymatic hydrolysis of lignocellulosic biomass (Chylenski et al., 2017). Two-stage enzymatic hydrolysis was carried out using five different enzyme mixture components. The chitin-rich biomass was also subjected to a total saccharification process using enzymatic cocktail. The DoE strategy included the use of five mono-component enzymes from Serratia marcescens, three chitinases, SmChiA, SmChiB, SmChiC, a lytic polysaccharide monooxygenase, SmLPMO10A, and a $\beta$-N-acetylhexosaminidase $(\mathrm{SmCHB})$. The enzymes were heterologously expressed in monogenic $E$. coli expression systems. The optimised enzyme cocktail resulted in the saccharification degree of shrimp and crab chitins of $70-75 \%$. Meanwhile, a "minimal" cocktail yielded only $40 \%$ saccharification (Mekasha et al., 2017). The increase of yield affirms the hypothesis that chitinolytic enzymes interact synergistically with each other in processing chitin and its derivatives. Of course, the DoE approach assumes a wider optimisation of the reaction conditions (enzymes, mix ratios, temperature, $\mathrm{pH}$, salt, and cofactors), but it does not assume the simultaneous production of biocatalysts in one host. Therefore, the costs of the processes are multiplied by the necessity to produce and purify recombinant enzymes that are involved in multi-enzyme cocktails.

Our research has shown that the use of polycistronic expression of chitin- and chitosanolytic enzymes using self-processing A2 
sequences has a real chance to overcome these limitations. Moreover, the use of efficient $P$. pastoris expression systems that produce small amounts of native extracellular proteins allows the application of raw culture medium as enzyme preparations significantly facilitating the recombinant proteins purification. However, careful examinations of the relationships between the efficiency of the expression of individual genes, their location in the multi-gene expression cassette, gene properties (size, spatial protein structure) and helper sequences (secretory sequences, A2 sequences) are still necessary.

\section{CONCLUSION}

In this work we have expressed and characterised two chitin deacetylases from $M$. circinelloides IBT-83 and utilised one of these proteins for the synthesis of the first eukaryotic, polycistronic expression system employing self-processing $2 \mathrm{~A}$ sequences containing three sequentially acting chitin processing enzymes. During the study it was shown that using viral selfprocessing sequences and degeneracy of the genetic code it is possible to stably express synergistically acting extracellular biocatalysts under control of the same promoter. These findings will hopefully translate into more effective conversion of chitin waste into their valuable derivatives: chitosan and chitooligosaccharides.

\section{DATA AVAILABILITY STATEMENT}

The original contributions presented in the study are included in the article/Supplementary Materials, further inquiries can be directed to the corresponding author.

\section{REFERENCES}

Al Sagheer, F. A., Al-Sughayer, M. A., Muslim, S., and Elsabee, M. Z. (2009). Extraction and Characterization of Chitin and Chitosan from marine Sources in Arabian Gulf. Carbohydr. Polym. 77, 410-419. doi:10.1016/ j.carbpol.2009.01.032

Andrés, E., Albesa-Jové, D., Biarnés, X., Moerschbacher, B. M., Guerin, M. E., and Planas, A. (2014). Structural Basis of Chitin Oligosaccharide Deacetylation. Angew. Chem. Int. Ed. 53, 6882-6887. doi:10.1002/anie.201400220

Blair, D. E., Hekmat, O., Schüttelkopf, A. W., Shrestha, B., Tokuyasu, K., Withers, S. G., et al. (2006). Structure and Mechanism of Chitin Deacetylase from the Fungal Pathogen Colletotrichum Lindemuthianum $\dagger, \ddagger$. Biochemistry 45, 9416-9426. doi:10.1021/bi0606694

Chatterjee, S., Adhya, M., Guha, A. K., and Chatterjee, B. P. (2005). Chitosan from Mucor Rouxii: Production and Physico-Chemical Characterization. Process Biochem. 40, 395-400. doi:10.1016/j.procbio.2004.01.025

Chen, X., Zhai, C., Kang, L., Li, C., Yan, H., Zhou, Y., et al. (2012). High-level Expression and Characterization of a Highly Thermostable Chitosanase from Aspergillus fumigatus in Pichia pastoris. Biotechnol. Lett. 34, 689-694. doi:10.1007/s10529-011-0816-0

Chylenski, P., Forsberg, Z., Ståhlberg, J., Várnai, A., Lersch, M., Bengtsson, O., et al. (2017). Development of Minimal Enzyme Cocktails for Hydrolysis of SulfitePulped Lignocellulosic Biomass. J. Biotechnol. 246, 16-23. doi:10.1016/ j.jbiotec.2017.02.009

De Felipe, P., Luke, G. A., Hughes, L. E., Gani, D., Halpin, C., and Ryan, M. D. (2006). E Unum Pluribus: Multiple Proteins from a Self-Processing Polyprotein. Trends Biotechnol. 24, 68-75. doi:10.1016/j.tibtech.2005.12.006

\section{AUTHOR CONTRIBUTIONS}

MBK: Conceptualization; Data curation, Formal analysis, Funding acquisition, Investigation, Methodology, Project administration, Resources, Validation, Visualization, Writing - original draft, Writing - review and editing; KS-S: Conceptualization; Methodology; MX: Investigation, Data curation, Visualization; MS-A: Conceptualization, Funding acquisition, Methodology, Project administration, Resources, Supervision; TA: Conceptualization, Funding acquisition, Methodology, Project administration, Resources, Supervision; MG: Data curation, Formal analysis, Investigation, Methodology, Validation; AS: Writing - review and editing; MD: Conceptualization, Data curation, Formal analysis, Funding acquisition, Project administration, Resources, Software, Supervision, Visualization, Writing - review and editing.

\section{FUNDING}

This research was funded by the Shenzhen Knowledge and Innovation Basic Research Grant JCYJ20180302153648993, to MD. The funders had no role in study design, data collection and analysis, interpretation, decision to publish, or preparation of the manuscript.

\section{SUPPLEMENTARY MATERIAL}

The Supplementary Material for this article can be found online at: https://www.frontiersin.org/articles/10.3389/fbioe.2021.710922/ full\#supplementary-material

De Kok, S. d., Stanton, L. H., Slaby, T., Durot, M., Holmes, V. F., Patel, K. G., et al. (2014). Rapid and Reliable DNA Assembly via Ligase Cycling Reaction. ACS Synth. Biol. 3, 97-106. doi:10.1021/sb4001992

Donnelly, M. L. L., Hughes, L. E., Luke, G., Mendoza, H., Ten Dam, E., Gani, D., et al. (2001a). The 'cleavage' Activities of Foot-And-Mouth Disease Virus 2A Site-Directed Mutants and Naturally Occurring '2A-like' Sequences. J. Gen. Virol. 82, 1027-1041. doi:10.1099/0022-1317-82-5-1027

Donnelly, M. L. L., Luke, G., Mehrotra, A., Li, X., Hughes, L. E., Gani, D., et al. (2001b). Analysis of the Aphthovirus 2A/2B Polyprotein 'cleavage' Mechanism Indicates Not a Proteolytic Reaction, but a Novel Translational Effect: A Putative Ribosomal 'skip'. J. Gen. Virol. 82, 1013-1025. doi:10.1099/0022-1317-82-5-1013

FAO (2017). Increased Production of Farmed Shrimp Leads to Improved International Trade. Food and Agriculture organizatioin of the United Nations. Available at: http://www.fao.org/in-action/globefish/market-reports/ resource-detail/en/c/989543/(Accessed September 4, 2020).

Gauthier, C., Clerisse, F., Dommes, J., and Jaspar-Versali, M.-F. (2008). Characterization and Cloning of Chitin Deacetylases From Rhizopus Circinans. Protein Expr. Purif. 59, 127-137. doi:10.1016/j.pep.2008.01.013

Geier, M., Fauland, P., Vogl, T., and Glieder, A. (2015). Compact Multi-Enzyme Pathways in P. Pastoris. Chem. Commun. 51, 1643-1646. doi:10.1039/c4cc08502g

Ghormade, V., Pathan, E. K., and Deshpande, M. V. (2017). Can Fungi Compete With marine Sources for Chitosan Production?. Int. J. Biol. Macromol. 104, 1415-1421. doi:10.1016/j.ijbiomac.2017.01.112

Grifoll-Romero, L., Pascual, S., Aragunde, H., Biarnés, X., and Planas, A. (2018). Chitin Deacetylases: Structures, Specificities, and Biotech Applications. Polymers (Basel) 10, 1-29. doi:10.3390/polym10040352

Guo, N., Sun, J., Wang, W., Gao, L., Liu, J., Liu, Z., et al. (2019). Cloning, Expression and Characterization of a Novel Chitosanase from Streptomyces 
Albolongus ATCC 27414. Food Chem. 286, 696-702. doi:10.1016/ j.foodchem.2019.02.056

Halpin, C., Cooke, S. E., Barakate, A., Amrani, A. E., and Ryan, M. D. (1999). Selfprocessing 2A-Polyproteins - a System for Co-ordinate Expression of Multiple Proteins in Transgenic Plants. Plant J. 17, 453-459. doi:10.1046/j.1365313X.1999.00394.x

Hayes, M. (2012). "Chitin, Chitosan and Their Derivatives from marine Rest Raw Materials: Potential Food and Pharmaceutical Applications," In Marine Bioactive Compounds: Sources, Characterization And Applications. Boston, MA: Springer, 1-229. doi:10.1007/978-1-4614-1247-2

Kaczmarek, M., Struszczyk-Świta, K., Struszczyk-Świta, K., Florczak, T., SzczęsnaAntczak, M., and Antczak, T. (2016). Isolation, Molecular Cloning and Characterisation of Two Genes Coding Chitin Deacetylase from Mucor Circinelloides IBT-83. Pcacd 21, 93-103. doi:10.15259/PCACD.21.09

Kaczmarek, M. B., Struszczyk-swita, K., Li, X., Szczęsna-Antczak, M., and Daroch, M. (2019). Enzymatic Modifications of Chitin, Chitosan, and Chitooligosaccharides. Front. Bioeng. Biotechnol. 7, 243. doi:10.3389/fbioe.2019.00243

Kjeldsen, T. (2000). Yeast Secretory Expression of Insulin Precursors. Appl. Microbiol. Biotechnol. 54, 277-286. doi:10.1007/s002530000402

Kolodziejska, I., Malesa-cieçwierz, M., Lerska, A., and Sikorski, Z. (1999). Properties of Chitin Deacetylase from Crude Extracts of Mucor Rouxii Mycelium. J. Food Biochem. 23, 45-57. doi:10.1111/j.1745-4514.1999.tb00004.x

Liang, Y., Tang, J., Luo, Y., Kaczmarek, M. B., Li, X., and Daroch, M. (2019). Thermosynechococcus as a Thermophilic Photosynthetic Microbial Cell Factory for CO2 Utilisation. Bioresour. Tech. 278, 255-265. doi:10.1016/ j.biortech.2019.01.089

Liu, P., Sehaqui, H., Tingaut, P., Wichser, A., Oksman, K., and Mathew, A. P. (2014). Cellulose and Chitin Nanomaterials for Capturing Silver Ions (Ag+) from Water via Surface Adsorption. Cellulose 21, 449-461. doi:10.1007/s10570-013-0139-5

Marei, N. H., El-Samie, E. A., Salah, T., Saad, G. R., and Elwahy, A. H. M. (2016). Isolation and Characterization of Chitosan from Different Local Insects in Egypt. Int. J. Biol. Macromol. 82, 871-877. doi:10.1016/j.ijbiomac.2015.10.024

Martinou, A., Kafetzopoulos, D., and Bouriotis, V. (1993). Isolation of Chitin Deacetylase from Mucor Rouxii by Immunoaffinity Chromatography. J. Chromatogr. A 644, 35-41. doi:10.1016/0021-9673(93)80117-Q

Mekasha, S., Byman, I. R., Lynch, C., Toupalová, H., Anděra, L., Næs, T., et al. (2017). Development of Enzyme Cocktails for Complete Saccharification of Chitin Using Mono-Component Enzymes from Serratia marcescens. Process Biochem. 56, 132-138. doi:10.1016/j.procbio.2017.02.021

Menghiu, G., Ostafe, V., Prodanovic, R., Fischer, R., and Ostafe, R. (2019). Biochemical Characterization of Chitinase A from Bacillus Licheniformis DSM8785 Expressed in Pichia pastoris KM71H. Protein Expr. Purif. 154, 25-32. doi:10.1016/j.pep.2018.09.007

Muzzarelli, R. A. A., Rocchetti, R., Stanic, V., and Weckx, M. (1997). Methods for the Determination of the Degree of Acetylation of Chitin and Chitosan. Chitin Handb, 109-119.

Nakamura, A. M., Nascimento, A. S., and Polikarpov, I. (2017). Structural Diversity of Carbohydrate Esterases. Biotechnol. Res. Innovation 1, 35-51. doi:10.1016/ j.biori.2017.02.001

Nelson, N. (1944). A Photometric Adaptation of the Somogyi for the Determination of Glucose. J. Biol. Chem. 153, 375-381. doi:10.1016/S00219258(18)71980-7

Nguyen, S. T. C., Freund, H. L., Kasanjian, J., and Berlemont, R. (2018). Function, Distribution, and Annotation of Characterized Cellulases, Xylanases, and Chitinases from CAZy. Appl. Microbiol. Biotechnol. 102, 1629-1637. doi:10.1007/s00253-018-8778-y

Pareek, N., Vivekanand, V., Agarwal, P., Saroj, S., and Singh, R. P. (2013). Bioconversion to Chitosan: A Two Stage Process Employing Chitin Deacetylase from Penicillium oxalicum SAEM-51. Carbohydr. Polym. 96, 417-425. doi:10.1016/j.carbpol.2013.04.005

Rath, A., Glibowicka, M., Nadeau, V. G., Chen, G., and Deber, C. M. (2009). Detergent Binding Explains Anomalous SDS-PAGE Migration of Membrane Proteins. Pnas 106, 1760-1765. doi:10.1073/pnas.0813167106

Roth, T. L., Milenkovic, L., and Scott, M. P. (2014). A Rapid and Simple Method for DNA Engineering Using Cycled Ligation Assembly. PLoS One 9, e107329-9. doi:10.1371/journal.pone.0107329

Sievers, F., and Higgins, D. G. (2018). Clustal Omega for Making Accurate Alignments of many Protein Sequences. Protein Sci. 27, 135-145. doi:10.1002/pro.3290
Sinha, J., Plantz, B. A., Inan, M., and Meagher, M. M. (2005). Causes of Proteolytic Degradation of Secreted Recombinant Proteins Produced in Methylotrophic yeastPichia Pastoris: Case Study with Recombinant Ovine Interferon-?. Biotechnol. Bioeng. 89, 102-112. doi:10.1002/bit.20318

Souza, C. P., Burbano-Rosero, E. M., Almeida, B. C., Martins, G. G., Albertini, L. S., and Rivera, I. N. G. (2009). Culture Medium for Isolating Chitinolytic Bacteria from Seawater and Plankton. World J. Microbiol. Biotechnol. 25, 2079-2082. doi:10.1007/s11274-009-0098-z

Struszczyk, M. H. (2000). Herstellung von Chitosan und einige Anwendungen. Available at: https://www.researchgate.net/publication/252779927_Herstellung von_Chitosan_und_einige_Anwendungen (Accessed January 24, 2017).

Suryawanshi, N., Jujjavarapu, S. E., and Ayothiraman, S. (2019). Marine Shell Industrial Wastes-An Abundant Source of Chitin and its Derivatives: Constituents, Pretreatment, Fermentation, and Pleiotropic Applications-A Revisit. Int. J. Environ. Sci. Technol. 16, 3877-3898. doi:10.1007/s13762-018-02204-3

Synowiecki, J., and Al-Khateeb, N. A. A. Q. (1997). Mycelia of Mucor Rouxii as a Source of Chitin and Chitosan. Food Chem. 60, 605-610. doi:10.1016/S03088146(97)00039-3

Synowiecki, J., and Al-Khateeb, N. A. (2003). Production, Properties, and Some New Applications of Chitin and its Derivatives. Crit. Rev. Food Sci. Nutr. 43, 145-171. doi:10.1080/10408690390826473

Szczesna-Antczak, M., Antczak, T., Piotrowicz-Wasiak, M., Rzyska, M., Binkowska, N., and Bielecki, S. (2006). Relationships between Lipases and Lipids in Mycelia of Two Mucor Strains. Enzyme Microb. Technol. 39, 1214-1222. doi:10.1016/j.enzmictec.2006.03.008

Thiago, R. d. S. M., Pedro, P. M. d. M., and Eliana, F. C. S. (2014). Solid Wastes in Brewing Process: A Review. J. Brew. Distill. 5, 1-9. doi:10.5897/jbd2014.0043

Tokuyasu, K., Ohnishi-Kameyama, M., and Hayashi, K. (1996). Purification and Characterization of Extracellular Chitin Deacetylase fromColletotrichum Lindemuthianum. Biosci. Biotechnol. Biochem. 60, 1598-1603. doi:10.1271/ bbb. 60.1598

Tuveng, T. R., Rothweiler, U., Udatha, G., Vaaje-Kolstad, G., Smalås, A., and Eijsink, V. G. H. (2017). Structure and Function of a CE4 Deacetylase Isolated from a marine Environment. PLoS One 12, e0187544-15. doi:10.1371/ journal.pone.0187544

Zhang, M., Puri, A. K., Govender, A., Wang, Z., Singh, S., and Permaul, K. (2015). The Multi-Chitinolytic Enzyme System of the Compost-Dwelling Thermophilic Fungus Thermomyces Lanuginosus. Process Biochem. 50, 237-244. doi:10.1016/j.procbio.2014.11.008

Zhang, S., Chen, Z., Wen, Q., Yang, L., Wang, W., and Zheng, J. (2016). Effectiveness of Bulking Agents for Co-composting Penicillin Mycelial Dreg (PMD) and Sewage Sludge in Pilot-Scale System. Environ. Sci. Pollut. Res. 23, 1362-1370. doi:10.1007/s11356-015-5357-y

Zhao, Y., Jo, G.-H., Ju, W.-T., Jung, W.-J., and Park, R.-D. (2011). A HighlyNGlycosylated Chitin Deacetylase Derived from a Novel Strain ofMortierellasp. DY-52. Biosci. Biotechnol. Biochem. 75, 960-965. doi:10.1271/bbb.110011

Zhu, X.-Y., Zhao, Y., Zhang, H.-D., Wang, W.-X., Cong, H.-H., and Yin, H. (2019). Characterization of the Specific Mode of Action of a Chitin Deacetylase and Separation of the Partially Acetylated Chitosan Oligosaccharides. Mar. Drugs 17, 74-15. doi:10.3390/md17020074

Conflict of Interest: The authors declare that the research was conducted in the absence of any commercial or financial relationships that could be construed as a potential conflict of interest.

Publisher's Note: All claims expressed in this article are solely those of the authors and do not necessarily represent those of their affiliated organizations, or those of the publisher, the editors and the reviewers. Any product that may be evaluated in this article, or claim that may be made by its manufacturer, is not guaranteed or endorsed by the publisher.

Copyright $\odot 2021$ Kaczmarek, Struszczyk-Swita, Xiao, Szczęsna-Antczak, Antczak, Gierszewska, Steinbüchel and Daroch. This is an open-access article distributed under the terms of the Creative Commons Attribution License (CC BY). The use, distribution or reproduction in other forums is permitted, provided the original author(s) and the copyright owner(s) are credited and that the original publication in this journal is cited, in accordance with accepted academic practice. No use, distribution or reproduction is permitted which does not comply with these terms. 